\title{
The factors influencing production and economic efficiency of beef cattle farm in Grobogan Region, Central Java
}

\author{
T. Ekowati*, E. Prasetyo and M. Handayani \\ Faculty of Animal and Agricultural Sciences, Diponegoro University, \\ Tembalang Campus, Semarang 50275 - Indonesia \\ *CorrespondingE-mail : tiekowati@yahoo.co.id \\ Received September 09, 2017; Accepted February 06, 2018
}

\begin{abstract}
ABSTRAK
Penelitian ini bertujuan untuk menganalisis pendekatan sub-sistem on-farm agribisnis pada rumah tangga petani, menganalisis faktor yang mempengaruhi produksi ternak dan menganalisis efisiensi usaha ternak sapi potong. Metode penelitian yang digunakan adalah metode survey di Kabupaten Grobogan, dengan dua kecamatan yakni Kecamatan Wirosari dan Kecamatan Purwodadi dan dua desa setiap kecamatan. Quota sampling method dilakukan untuk menentukan jumlah sampel rumah tangga peternak sapi potong induk-anak tanpa menghitung populasi sebagai sample frame. Jumlah responden setiap desa adalah 20 petani sehingga total responden 80 petani. Data dianalisis dengan pendekatan sistem agribisnis, analisis regresi lineer berganda dan efisiensi ekonomi usaha tani. Hasil penelitian menunjukkan bahwa penerapan on-farm agribisnis berada pada kondisi sedang sampai dengan baik, faktor yang mempengaruhi produksi sapi potong adalah skala usaha, hijauan pakan, konsentrat, kesehatan, reproduksi, tenaga kerja, lama beternak dan penerapan agribisnis. Efisiensi reproduksi usaha ternak adalah 8,975 lebih dari 1 sehingga tidak efisien dan efisiensi skala usaha, pakan, konsentrat, kesehatan dan tenaga kerja masing-masing 0,$352 ; 0,128 ; 0,0148 ; 0,0235$ dan 0,0834 yang kurang dari 1 sehingga belum efisien. Kesimpulan dari penelitian adalah usaha ternak sapi potong merupakan usaha agribisnis yang dapat dilanjutkan dengan memperhatikan faktor yang berpengaruh terhadap produksi, yaitu skala usaha, hijauan pakan, konsentrat, kesehatan, reporoduksi, tenaga kerja, lama beternak dan penerapan agribisnis. Faktor produksi skala usaha, hijauan pakan, konsentrat, kesehatan dan tenaga kerja belum efisien, sedangkan faktor reproduksi adalah faktor yang tidak efisien.
\end{abstract}

Kata kunci: on farm agribisnis, efisiensi, rumah tangga petani, sapi potong

\begin{abstract}
The study was aimed to analyze the on-farm agribusiness subsystem approach at farm household, to analyze beef cattle production influencing factors and to analyze economic efficiency of beef cattle farm. The method use for research was survey method at Wirosari District and Purwodadi District, Grobogan Regency as research location. Each district was determined two villages to obtain data from respondent. Quota sampling method was use for determination the number of beef cattle farm household without a counting of population as a sampling frame. The number of respondent for each village was 20 farmers, so the total respondent was 80 farmers. Data were analyzed descriptively for on farm subsystem agribusiness approach, multiple linear regression and economic efficiency. The research result showed that the on-farm agribusiness subsystem was on moderate to good condition, the influencing factors of production were breed, forage, concentrate, health, reproduction, labor, year of farming and agribusiness implementation. The value of reproduction efficiency was 8.975 higher than 1 , it was not efficient. The efficiency of farm scale, forage, concentrate, health and labor were $0.352 ; 0.128 ; 0.0148$; 0.0235 and 0.0834 respectively less than 1 , and it had not been efficient yet. The conclusion of research
\end{abstract}


was the agribusiness implementation in beef cattle farming was in moderate and good criteria and gave the benefit to farmers. Production factors of farm scale, forage, concentrate, health, reproduction, labor, years of farming and agribusiness implementation were influence to the beef cattle production. The efficiency of farm scale, forage, concentrate, health, and labor on the beef cattle farm were not been efficient yet, while reproduction became an inefficient production factor.

Keywords : on-farm agribusiness, beef cattle, efficiency, farm household

\section{INTRODUCTION}

Development of agricultural sector, especially livestock husbandry sub-sector should be developed in order to create an efficient and competitive agriculture, as well as able to increase the income and the living standard of farmers and ranchers in particular and public in general. The development is achieved through enhancement of agribusiness pattern, especially improvement of production's quality and quantity, diversification of superior commodities, improvement of products' value-added, capital and expansion of market share (Bakhshineja, 2015).

One of the potential agricultural commodities with an economic value to be developed is beef cattle. This is because the farmer's households which generally focused on crop farming sub-sector and livestock sub-sector are not fully implement the agribusiness system approach yet, so farming efficiency has not been reached and ultimately impacted to unoptimal farming.

Beef cattle breeding business in Indonesia is dominated by a cow-calf system for feeder cattle provision, as well as the case in Central Java and particularly in Grobogan Regency. This business is almost $90 \%$ practiced by animal farmers which generally does not implement the concept of intensive business. The non-systemized maintenance and feeding system with a quite long maintenance time makes this effort is economically less profitable than fattening. However, people breeding of beef cattle still exist until today because it is operated in an integrated system with crop farming. An Ongole Grade cattle (Peranakan Ongole, PO) is local cattle which has potential to be developed due to its high adaptability towards tropical environment.

Producer's purpose in managing its farming is to increase production and profits. The basic assumption behind the efficiency is to achieve maximum benefit with minimum cost. Both of these goals are the determining factor for beef cattle's farmer in their decision making on farming (Sarma and Ahmed, 2011). In making decision on farming, a rational farmer would be willing to use the input as long the value added generated by the additional input is equal to or greater with additional costs resulted from the additional input. Efficiency is the ratio of output to input used in a production process. In general, the concept of efficiency was viewed from two perspectives, namely the allocation of input use and the output produced. Approach from the input perspective suggested by Fleming et al. (2010), requires the availability of information regarding input price used to maximally produce the output. While approach from output perspective means that it is used to see how far the amount of output can be proportionally increased without changing the amount of inputs used.

The use of production factors can affect production output and efficiency. This could not be separated from the agribusiness system applied, particularly the six proper use of input factors, namely on time, quantity, grade, product, price and quality. All of these factors are a series that can affect the efficient use of the factor inputs. Crucial factors for the development of beef cattle commodity are competitiveness and government's support. Efficiency as one of determinants of competitiveness needs to be considered in the development of this commodity. Government's intervention will affect the competitiveness of a commodity system. Of the many households absorbed in agricultural sector, the farming-livestock breeding apparently not give any good results, meaning that the efforts undertaken have not efficient yet. Farminglivestock breeding in farmer households with an agribusiness approach is a study which combines a subsystem concept of agribusiness with purpose to improve the use of production facilities so that a better production can be resulted (Ekowati et al., 2011). The productivity of a good farminglivestock breeding can be achieved if the combination of production factors can be managed properly. The increased productivity of farming-livestock breeding can be achieved if there is an efficient allocation of production factors to gain an efficient result. Efficiency 
analysis is used to determine the efficiency level of production factors used in farming-livestock breeding. The highest economic efficiency is achieved when the maximum profits are gained. The improvement of production factors used is also correlated to the availability of production facilities for farming-livestock breeding.

Productivity and efficiency are the core determinants of competitiveness (Ningsih et al., 2016). A commodity will be able to compete in the market if it has a high competitiveness. High competitiveness is reflected by a good price and quality. However, the problem exists if the commodities produced could not compete. Comparative and competitive advantages of a commodity depend on several key factors including market diversity. In addition, government's intervention in the form of policy will also affect the comparative and competitive advantages of a commodity system. Data and information regarding comparative and competitive advantages becomes one consideration in policy formulation and implementation. In considering efficiency and competitiveness, it can be traced and further formulated what factors which dominantly influence beef cattle production and its production efficiency. In the end, if there has seen an overall view of a beef cattle commodity system, it can be said that efficiency is closely related to the improved competitiveness and farmer's income. Efficiency will lead to a decrease in production costs, which in turn will improve competitiveness. Therefore, this research is very important. The objectives of the research were to describe an approach of on-farm agribusiness sub-systems in beef cattle farm, analyze factors affecting the production of beef cattle farm and to analyze the economic efficiency of beef cattle farm.

\section{MATERIALS AND METHODS}

This study was conducted with survey method by collecting a sample from the existed population (Nasir, 1988) with a purpose to investigate the condition of farmer households, particularly cow-calf system in beef cattle farm.

Purposive is established for determining the research location based on the potential which rooted in cattle population in Central Java. Based on the data in Agriculture and Livestock Statistics 2015, there was known that Grobogan is regency which has potential for beef cattle farm in Central Java.

\section{Methods of Sampling and Data Collection}

Based on the sample, there are two districts determined based on the beef cattle population and presence and activity of farmer groups, namely Wirosari District and Purwodadi District. Of the selected districts, there are two villages selected from each of them, namely Karangasem and Sambirejo Villages from Wirosari District with farmer groups named Mugi Barokah and Sendang Mulyo, while Nambuhan and Genuk Suran Villages are selected from Purwodadi District with Ngudi Rejeki and Tani Makmur as their farmer groups.

Quota sampling method was taken to determine the sample number of cow-calf breeder without counting the number of population as the sample frame. In this study, the sample number of beef cattle breeder from each village is 20 farmers, thus the number of respondent is 80 farmers (farmer households).

\section{Analysis Methods}

Methods used to analyze each objective were:

1. The objective 1 was analyzed by descriptive to describe the development of on-farm agribusiness sub-system implementation, regarding the use of production facilities with a "Six Precise" approach in term of the precise of right time, amount, grade, quality, product, and price which is analyzed using scoring value with Likert Scale. The values of likert scale are 5, 4, 3, 2, and 1 for very good, good, moderate, somewhat good and not good, respectively

2. Objective 2 was analyzed using multiple linear regression analysis

Soekartawi et al. (2003) stated that Cobb Douglas production is a good production function to use in industry and agriculture. The original form of the Cobb-Douglas function is as follows:

$$
\mathrm{Y}=\mathrm{bX}_{1}^{\mathrm{a} 1} \mathrm{X}_{2}^{\mathrm{a} 2}, \ldots ., \mathrm{bX}_{\mathrm{n}}^{\mathrm{an}}
$$

Where

Y : Variable described

$\mathrm{X}$ : Variable that describe

a2, a3 The amoun of estimeted

$\mathrm{u} \quad$ : Resideual elements (error)

e $\quad$ : Natural logarithm $(\mathrm{e}=2.718)$

Gujarati (2006) explained the model has X 
variable that is not linear, and natural logarithm was used to make it linear, so the equation is as follows:

$\ln \mathrm{Y}=\mathrm{a}+\mathrm{a}_{1} \ln \mathrm{X}_{1}+\mathrm{a}_{2} \ln \mathrm{X}_{2}+\ldots \ldots+\mathrm{a}_{\mathrm{n}} \ln \mathrm{X}_{\mathrm{n}}+$ $\mathrm{u}_{1}$

3. Objective 3 was analyzed using analysis of economic efficiency

The number of production elasticity may indicates Return to Scale (RTS), where it can be used to determine whether the farming activity is experiencing increasing, constant, or decreasing returns to scale' and can demonstrate production efficiency technically. There are three alternatives that could occur in the RTS:

a. Decreasing returns to scale, if $(\mathrm{a} 1+\mathrm{a} 2$ $+\mathrm{a} 3+\ldots .+$ an $)<1$, meaning that the proportion of production factors added exceeds the proportion of added production.

b. Constant return to scale, if $(\mathrm{a} 1+\mathrm{a} 2+$ $\mathrm{a} 3+\ldots .+\mathrm{an})=1$, meaning that the proportion of production factors added will be equal to the proportion of added production.

c. Increasing returns to scale, if $(\mathrm{a} 1+\mathrm{a} 2+$ a3 $+\ldots .+$ an $)>1$, meaning that the proportion of added production exceeds the proportion of production factors added.

Analysis of economic efficiency is normally used to determine the optimation level of production factors use. The highest economic efficiency is achieved when the profits reach a maximum level.

$$
\begin{aligned}
\text { Profit }= & \text { Total Revenue }- \text { Total Cost } \\
= & (\text { Production } \mathrm{x} \text { Product Price })- \\
& (\text { Variable Costs }+ \text { Fixed Costs }) \\
= & (\text { Y. Py })-(\mathrm{X} . \mathrm{Px}+\mathrm{TFC}) \ldots . . . \ldots \ldots . . .
\end{aligned}
$$

Maximum profit occurs when the first derivative of profit function $=0$

$\mathrm{dY} / \mathrm{dX}=0$

$\mathrm{dY} / \mathrm{dX} . \mathrm{Py}-\mathrm{Px}=0$

$\mathrm{dY} / \mathrm{dX} . \mathrm{Py}=\mathrm{Px} \rightarrow \mathrm{MPx} . \mathrm{Py}=\mathrm{Px}$

Soekartawi (2003) mentioned that the economic efficiency occurs when the value of marginal product of each additional unit of input is equal to the price of each unit of these inputs which can be written as follows:

$\mathrm{MPVx}=\mathrm{Px}$
Where:

MPVx $=$ The value of marginal product of input $\mathrm{X}$ $\mathrm{Px}=$ Input price

Economic efficiency $=\mathrm{MPV} / \mathrm{MC}$

Where calculating MVP $=\beta x i$. Y / xi. Py and calculating $\mathrm{MC}=\mathrm{P}_{\mathrm{XI}}$

Where :

MVP $=$ Marginal Value Product

$\mathrm{MC}=$ Marginal Cost

$\beta \mathrm{xi}=$ Regression coefficient of each production factor

$\mathrm{P}_{\mathrm{XI}}=$ Price of the- ...i... production factors (input prices)

Py $=$ Output price

However, the case mostly found is MVPx not always equal to $\mathrm{Px}$ :

a. (MVPxi $) /($ Pxi $)>1$, meaning that the use of inputs ( $\mathrm{x})$ is not efficient, in this condition input $(\mathrm{x})$ still can be added.

b. (MVPxi $) /($ Pxi $)<1$, meaning that the input use is not efficient, input ( $\mathrm{x}$ ) need to be reduced.

\section{RESULTS AND DISCUSSION}

Respondent of farmers in majority were in the productive age (83\%) with $100 \%$ worked as farmers, $41.90 \%$ of them have education level of junior high school and $42 \%$ of farming period which was between 11-20 years, with livestock ownership of $57 \%$ which was approximately $2.5-$ 3.5 Animal Unit (AU). These conditions, among others, can affect the implementation of input use and beef cattle production.

The implementation of upper-agribusiness subsystem reflects the condition of farmers regarding the use of production facilities with a "Six Precise" approach including the right time, amount, grade, quality, product, and price. The results of on-farm agribusiness subsystem implementation was a variable used as one of variables to analyze the production, beef cattle breeding, and the efficient use of input factors.

The implementation of each on-farm agribusiness subsystem is presented in Table 1. The implementation of each on-farm agribusiness subsystem using the 'six precise' approach to the input factors usage was at moderate to good category. The cattle stock was supplied with "Good" by farmers on time approach, while the health use can be categorized into "Good" 
Table 1. The Precise of On-Farm Agribusiness Subsystem Implementation of Beef Cattle Farm

\begin{tabular}{|c|c|c|c|c|c|c|}
\hline \multirow{2}{*}{$\begin{array}{l}\text { Production } \\
\text { Factor }\end{array}$} & \multicolumn{6}{|c|}{ Agribusiness Subsystem Implementation } \\
\hline & Time & Number & Type & Grade & Product & Price \\
\hline & & & 0 & & & \\
\hline Breed & $\begin{array}{l}\text { Good } \\
(44.5)\end{array}$ & $\begin{array}{l}\text { Moderate } \\
(40.5)\end{array}$ & $\begin{array}{c}\text { Moderate } \\
\text { (48) }\end{array}$ & $\begin{array}{c}\text { Moderate } \\
(41.5)\end{array}$ & $\begin{array}{c}\text { Moderate } \\
(50)\end{array}$ & $\begin{array}{c}\text { Moderate } \\
\text { (60) }\end{array}$ \\
\hline Forage & $\begin{array}{l}\text { Moderate } \\
\quad(40)\end{array}$ & $\begin{array}{l}\text { Moderate } \\
(48)\end{array}$ & $\begin{array}{l}\text { Moderate } \\
(42)\end{array}$ & $\begin{array}{l}\text { Moderate } \\
(41.4)\end{array}$ & $\begin{array}{c}\text { Moderate } \\
(46)\end{array}$ & $\begin{array}{c}\text { Moderate } \\
\text { (48) }\end{array}$ \\
\hline Concentrate & $\begin{array}{l}\text { Moderate } \\
\quad(40)\end{array}$ & $\begin{array}{c}\text { Moderate } \\
\text { (42) }\end{array}$ & $\begin{array}{l}\text { Moderate } \\
\quad(44.5)\end{array}$ & $\begin{array}{l}\text { Moderate } \\
(44.5)\end{array}$ & $\begin{array}{l}\text { Moderate } \\
\text { (43) }\end{array}$ & $\begin{array}{c}\text { Moderate } \\
\text { (49) }\end{array}$ \\
\hline Medicine & $\begin{array}{l}\text { Good } \\
(40.5)\end{array}$ & $\begin{array}{c}\text { Good } \\
(41)\end{array}$ & Good (40.5) & Good (38.5) & $\begin{array}{c}\text { Moderate } \\
\text { (42) }\end{array}$ & $\begin{array}{c}\text { Moderate } \\
(46.5)\end{array}$ \\
\hline Reproduction & Good (40.5) & $\begin{array}{c}\text { Moderate } \\
\text { (42) }\end{array}$ & $\begin{array}{l}\text { Moderate } \\
\text { (41) }\end{array}$ & $\begin{array}{l}\text { Moderate } \\
(42.5)\end{array}$ & $\begin{array}{c}\text { Moderate } \\
\text { (43) }\end{array}$ & $\begin{array}{c}\text { Moderate } \\
(44.4)\end{array}$ \\
\hline Labor & $\begin{array}{l}\text { Moderate } \\
(40.5)\end{array}$ & $\begin{array}{l}\text { Moderate } \\
(45)\end{array}$ & $\begin{array}{l}\text { Moderate } \\
(42.5)\end{array}$ & $\begin{array}{l}\text { Moderate } \\
(42.0)\end{array}$ & $\begin{array}{c}\text { Moderate } \\
\quad(45.0)\end{array}$ & $\begin{array}{c}\text { Moderate } \\
(48.5)\end{array}$ \\
\hline
\end{tabular}

condition based on the timing, amount, type and quality. The use of feed production facilities, labor and some reproductions were in "Medium" condition. Based on this condition, an improvement becomes a requirement with regard to accessibility, supported facilities, and capital resources. This condition reflects whether the livestock business was efficiently operated or not. That this condition happened due to the high price of cattle, the forage availability which was less in dry season, the high price of concentrates and medicines, access barrier to get the good quality cattle as well as level of education and labor number (Ekowati et al., 2011). Farmers with beef cattle breeding of 2.5 cattle units required production costs of IDR 8,095,927.19 per year with the highest cost of IDR 3,760, 560 (46.45\%) allocated for forage. Labor cost also became an allocation greatly incurred by many farmers, given the rare availability of family labor, thus a special cost needed to be sacrified for this, which amounted to IDR $3,274,875.00$ (40.45\%). The income of beef cattle farm was IDR $1,041,860.32$ year with the profitability was $12.87 \%$. That result faced to the Bakhshinej (2015) that cattle fattening enterprise is profitable alternative income opportunities in rural areas. Most of the participating farms were satisfied with the supplemental net income earning from cattle fattening with short duration.
The cost production of beef cattle farm is presented at Table 2. Meanwhile, the revenue and beef cattle farm income is presented in Table 3. The results of normality test showed that the value of all variables was greater than 0.05 , means normal; the Durbin-Watson value was 1.873 or there was no autocorrelation and VIF value was smaller than 10 , so there was no multikolinearitas happened to the data..

The results of regression analysis towards beef cattle business showed that variables of farm scale, forage, concentrate, medicine, reproduction, labor, years of farming and on farm subsystem agribusiness implementation were simultaneously influenced the beef cattle production with significance of 0.000 . The coefficient values of determination $\mathrm{R}^{2}$ and adjusted $\mathrm{R}^{2}$ were 0.668 and 0.631 , respectively, which means $63.1 \%$ of beef cattle production was affected by variables of farm scale, forage, concentrate, health, reproduction, labor, year of farming and on farm subsystem agribusiness implementation, and it was faced to Ekowati et al. (2012).

$$
\mathrm{Y}=-2.147+1.108 \mathrm{X}_{1}+0.081 \mathrm{X}_{2}+0.020 \mathrm{X}_{3}
$$
$+0.032 \mathrm{X}_{4}+0.143 \mathrm{X}_{5}+0.453 \mathrm{X}_{6}-0.026 \mathrm{X}_{7}+$ $0.158 \mathrm{X}_{8}+\mathrm{u}$

The result of regression analysis is presented in Table 4. Based on the analysis results, it was suggested that variables that 
Table 2. Production Cost of Beef Cattle Farm

\begin{tabular}{lrr}
\hline \multicolumn{1}{c}{ Component } & \multicolumn{1}{c}{$\begin{array}{c}\text { Production } \\
\text { Cost } \\
\text { (IDR/year })\end{array}$} & Percentage \\
\hline Fixed cost & & \\
- Land Tax & $14,376.00$ & 0.177 \\
- Depreciation & $369,830.87$ & 4.568 \\
- Farmer's Goup & $8,700.00$ & 0.107 \\
contribution & & \\
& & \\
Variable cost & & \\
- Forage & $3,760,560.00$ & 46.450 \\
- Concentrate & $617,132.19$ & 7.623 \\
- Health & $6,203.13$ & 0.076 \\
- Reproduction & $44,250.00$ & 0.546 \\
- Labor & $3,274,875.00$ & 40.450 \\
Total & $8,095,927.19$ & 100.000 \\
\hline
\end{tabular}

Table 3. Beef Cattle Farm Income

\begin{tabular}{lc}
\hline \multicolumn{1}{c}{ Component } & Income ( IDR/2.5 AU/year) \\
\hline Revenue & $9,116,975.00$ \\
Cost & $8,095,927.19$ \\
Income & $1,041,860.32$ \\
\hline
\end{tabular}

influence the beef cattle production were farm scale, forage, concentrate, health, reproduction, year of farming and on farm agribusiness implementation. Each of them affects the beef cattle production. Whereas, farm scale was the dominant variable affecting beef cattle production and labor as well.

This was consistent with the results of Ekowati et al. (2011) and Kalangi et al. (2014) stating that farm scale was essential for livestock breeding and because the small-scaled breeding will not be efficient for input factor excertion so that the production also will not give a good result. In addition, another crucial thing to be considered in this factor was agribusiness implementation, where there was 'six right' approach implemented to show that the right allocation of production factors actually impacted to livestock production. Furthermore, the on farm subsystem agribusiness implementation surely can also determine whether the input factors are efficiently used or not by breeders. Labor is the number of hours worked per week by the producer in an off-farm job. On the one hand, it can be expected that the more off-farm hours a producer works, the less time is devoted to the cattle operation, resulting in lower production and lower efficiency. Alternatively, an off-farm job may force a producer to become a better manager, and become more efficient in the use of resources to compensate for the time spent off-farm (Rakipova et al., 2003).

\section{Economic Efficiency Analysis of Beef Cattle Breeding}

Efficiency is a concept describing about to which extent the production factors used has been able to deliver the maximum results in term of physical product or profit (Ceyhan and Heznezi, 2010; Sarma et al., 2014). In an agricultural context, efficiency is a concept that shows the effectiveness level of production factors such as land, labor, and other factors used in farming.

Farming scale or Return to Scale (RTS) was used to determine whether the farming activity is experiencing increasing, constant, or decreasing returns to scale rules. RTS value is obtained by summing all regression coefficient values of the variable inputs used. RTS value from the sum of regression coefficient also shows the production elasticity that was greater than one, less than one, or equal to one. There are three possible alternatives:

a. Decreasing return to scale, if $(\mathrm{a} 1+\mathrm{a} 2+$ a $3+\ldots+$ an) $<1$, meaning that the proportion of production factors added exceeds the proportion of added production.

b. Constant return to scale, if $(\mathrm{a} 1+\mathrm{a} 2+\mathrm{a} 3$ $+\ldots+$ an $)=1$, meaning that the proportion of production factors added will be equal to the proportion of added production.

c. Increasing returns to scale, if $(\mathrm{a} 1+\mathrm{a} 2+$ a $3+\ldots .+$ an $)>1$, meaning that the proportion of added production exceeds the proportion of production factors added.

Table 5 described that the sum of regression coefficients of variables in beef cattle farm was 2.021 greater than 1 . It showed that livestock 
Table 4. Regression Analysis of Beef Cattle Production

\begin{tabular}{lccc}
\hline \multicolumn{1}{c}{ Variable } & $\begin{array}{c}\text { Regression } \\
\text { Coefficient }\end{array}$ & P Value & Note \\
\hline Farm scale $\left(\mathrm{X}_{1}\right)$ & 1.108 & 0.000 & Significant \\
Forage $\left(\mathrm{X}_{2}\right)$ & 0.081 & 0.060 & Significant \\
Concentrate $\left(\mathrm{X}_{3}\right)$ & 0.020 & 0.010 & Significant \\
Health $\left(\mathrm{X}_{4}\right)$ & 0.032 & 0.040 & Significant \\
Reproduction $\left(\mathrm{X}_{5}\right)$ & 0.143 & 0.009 & Significant \\
Labor $\left(\mathrm{X}_{6}\right)$ & 0.453 & 0.011 & Significant \\
Year of farming $\left(\mathrm{X}_{7}\right)$ & -0.026 & 0.043 & Significant \\
Agribusiness Subsystem Implementation $\left(\mathrm{X}_{8}\right)$ & 0.158 & 0.004 & Significant \\
\hline
\end{tabular}

Table 5. Return to Scale of Beef Cattle Farm

\begin{tabular}{lc}
\hline \multicolumn{1}{c}{ Production Factors } & $\begin{array}{c}\text { Regression } \\
\text { Coefficient }\end{array}$ \\
\hline Farm scale & 1.108 \\
Forage & 0.081 \\
Concentrate & 0.020 \\
Health & 0.032 \\
Reproduction & 0.143 \\
Labor & 0.453 \\
Year of farming & -0.026 \\
Agribusiness Subsystem & 0.158 \\
implementation & 2.021 \\
\hline Return to Scale (RTS) & \\
\hline
\end{tabular}

farming in Grobogan Regency was in the increasing returns to scale rule. It mean that each fixed production factor added in the long term will increase the production of beef cattle. It was faced to Featherstone et al. (1997) that 62 farms were operating in the region of increasing returns to scale. Therefore, a farm expansion was needed to lower the average cost of livestock farming in order to raise farmer's income. Increasing the scale of farm will decrease the cost for per cattle and will increase efficiency in production. However, the interviews with farmers about the necessary sources in order to increase cattle numbers have showed that they have finite opportunities because only large farm scale had sufficient to cover the capital (Ozden and Armagan, 2014).

Efficiency reflects the use of several inputs to produce a product that can give a maximum profit (Rakipova et al., 2003). The study results regarding the efficiency of beef cattle breeding in Grobogan Regency are presented in Table 6.

The value of reproduction efficiency was 8.975 higher than 1 , it was not efficient. The efficiency of farm scale, forage, concentrate, health and labor were $0.352 ; 0.128 ; 0.0148$; 0.0235 and 0.0834 respectively less than 1 , and it had not been efficient yet. This was consistent with Herani et al. (2008) that the use of the input feed, concentrates and energy was not efficient thus needs to be reduced. Meanwhile, production factor of reproductive system needs to be improved even though IB value gained of 1.6 was categorized into Good.

When further examined, production factors such as livestock provision, forage, concentrate, health, reproduction, and labor were influence beef cattle farm production, as well as the on farm subsystem agribusiness implementation. However, the use of input factor incurred by farmers for beef cattle farm has not been and was not efficient. It was faced to Gomes et al. (2015) that pointed out sources of inefficiency in terms of input with low qualification. When properly observed, the application of "Six Right" approach in agribusiness showed that indicators farm scale forage, concentrate, health and labor were in "Moderate" condition. This explains the reason why production factors such as farm scale, forage, 
Table 6. Economics Efficiency of Production Factors Usage at Beef Cattle Farm

\begin{tabular}{lrrrrrr}
\hline \multicolumn{1}{c}{$\begin{array}{c}\text { Production } \\
\text { Factors }\end{array}$} & $\begin{array}{c}\text { Average of } \\
\text { Input }\end{array}$ & $\begin{array}{c}\text { Regression } \\
\text { Coeff. }\end{array}$ & $\begin{array}{c}\text { Marginal } \\
\text { Product } \\
\text { (MPxi) }\end{array}$ & $\begin{array}{c}\text { Marginal } \\
\text { Value Product } \\
\text { (MVPxi) }\end{array}$ & $\begin{array}{c}\text { Input Price } \\
\text { (Pxi) }\end{array}$ & $\begin{array}{c}\text { MVPxi/ } \\
\text { Pxi }\end{array}$ \\
\hline Farm scale & 2.513 & 1.108 & 0.441 & $2,646.000$ & $7,500,000$ & 0.352 \\
Forage & $24,484.5$ & 0.081 & 0.0000033 & 19.86 & 155 & 0.128 \\
Concentrate & 538.681 & 0.020 & 0.000004 & 22.26 & 1,500 & 0.0148 \\
Health & 2.037 & 0.032 & 0.0157 & $94,256.26$ & 4,000 & 0.0235 \\
Reproduction & 1.6 & 0.143 & 0.0893 & 536,250 & 60,000 & 8.975 \\
Labor & 86.85 & 0.453 & 0.0052 & $31,295.34$ & 37,500 & 0.0834 \\
\hline Production (Y) & & 1 & & & & \\
Calf price (Py) & $6,000,000$ & & & & \\
\hline
\end{tabular}

MPxi $=($ regression coefficient $x$ Production $) /$ average input

MVPxi $=$ MPxi x Py

concentrate, health and labor was not efficient thus needs to be reduced in order to minimize the production cost. Meanwhile, reproduction should be added to increase the production farm. Based on these conditions, then an understanding regarding the standard use of input factor in beef cattle farm becomes a requirement. The standard of the forage usage per $\mathrm{AU}$ per day is approximately $10 \%$ body weight/day, or approximately $3 \mathrm{~kg}$ per day or $90 \mathrm{~kg}$ per head per day, the use of forage input factor was 24.484,5. From this amount, it can be seen that the forage use is still low so it needs to be added.

\section{CONCLUSION}

Based on the study results, it can be concluded that: the agribusiness implementation in beef cattle farming was still in moderate and good criteria and give the benefit to farmers. Production factors of farm scale, forage, concentrate, health, reproduction, labor, farming duration, and agribusiness implementation were influence to the beef cattle production. Production factors of farm scale, forage, concentrate, health, and labor on the beef cattle farm were not been efficiently applied. While reproduction became an inefficient production factor.

\section{ACKNOWLEDGMENTS}

The research was supported by Diponegoro
University Research Grant of Implementation and Development Research the year of 2016, Number of contract: 1051-58./UN7.5.1/PG/2016

\section{REFERENCES}

Bakhshinejad, M. 2015. Economic analysis of small scale cow fattening In Iran. Research J. Fish. Hydrobiol. 10(9):394-399

Ceyhan, V. and K. Hazneci. 2010. Economic efficiency of cattle farms in Amasya Province, Turkey. J of Anim. Vet. Adv. 9(1):60-69.

Ekowati, T., D.H. Darwanto, S. Nurtini and A. Suryantini. 2011. The Analysis of beef cattle subsystem agribusiness implementation in Central Java Province. J. Indonesian Trop. Anim. Agric.. 36(4):281-289.

Ekowati, T., D.H. Darwanto, S. Nurtini and A. Suryantini. 2012. A Supporting aid for beef cattle investment of farm household in Central Java Province. J. Indonesian Trop. Anim. Agric. 37(1):41-49

Featherstone, A. M., M. R. Langemeier and M. Ismet. 1997. A nonparametric analysis of efficiency for a Sample of Kansas Beef Cow Farms. J. of Agric and Appl Ec. 29(1):175184

Fleming E, P. Fleming, G. Griffith and D. Johnston. 2010. Measuring beef cattle efficiency in Australian feedlots : Applying technical efficiency and productivity 
analysis methods. Aust. Agribusiness Review. 18:43-65

Gomes, E. G., E. G., U. G. P. de Abreu, J. C. C.B. S. de Mello, Th.B. de Carvalho and S. de Zen. 2015. Economic and socioenvironmental performance assessment of beef cattle production systems: a data envelopment analysis (DEA) approach with weight restrictions. R. Bras. Zootec. 44(6):219-225

Gujarati, D.N. 2006. Dasar-Dasar Ekonometrika. Edisi Ketiga. Penerbit Erlangga, Jakarta.

Herani, G. M., Pervez, M.Wasim, Rajar, A.Wasayo and S.R.A. Indus. 2008. Livestock: A Reliable Source of Income Generation and Rehabilitation of Environment at Tharparkar Institute of Higher Education, Karachi University, Sindh University, BIZTEK.

Kalangi, L. S., Y. Syaukat., S. U. Kuntjoro and A. Priyanti. 2014. Technical efficiency of beef cattle breeding business in East Java Province. Media Peternakan. 37(2):136-142.

Nasir, M. 1988. Metode Penelitian. Ghalia Indonesia. Jakarta.

Ningsih, W. U., B. Hartono, B. A. Nugroho and
H. D. Utami. 2016. Analysis of technical, allocative and economical efficiency in small beef Cattle farming (A Case Study in Tumpang Sub-district, Malang Regency). IJER (C) Serials Publications 13(1): 165-174

Ozden, A and G. Armagan. 2014. Efficiency analysis on cattle fattening in turkey. Veterinarija ir zootechnika (Vet Med Zoot). 67(89):88-93

Rakipova, A. N., J. M. Gillespie and D. E. Franke. 2003. Determinants of technical efficiency in Louisiana Beef Cattle Production. J. ASFMRA. 22:99-107.

Sarma, P. K. and J. U. Ahmed. 2011. An economic study of small scale cattle fattening enterprise of Rajbari district. J. Bangladesh Agril. Univ. 9(1):141-146.

Sarma, P. K., S. K. Raha and H. Jørgensen. 2014. An economic analysis of beef cattle fattening in selected areas of Pabna and Sirajgonj Districts. J. Bangladesh Agril. Univ. 12(1):127-134

Soekartawi. 2003. Teori Ekonomi Produksi Dengan Pokok Bahasan Analisis Fungsi Cobb Douglas. RajaGrapindo. Jakarta. 